\title{
Spousal Violence Against Women in the UAE Society
}

\author{
Khawla A. AlMulla* \\ Dr. Husein M. Alothman**
}

\section{Abstract}

The study aims at uncovering the magnitude and patterns of violence committed against married women by their husbands in the UAE society. The study also aims to find out the most important factors associated with patterns of perpetrating physical, psychological and sexual violence. A questionnaire was used to collect data from 920 married women from various emirates in the UAE, where percentages and Pearson correlation coefficients were used to answer the study questions and achieve its objectives.

Results show that psychological violence is the most common among married women, followed by physical and sexual violence respectively, and that a large proportion of married women under went both psychological and physical violence whereas a small percentage of married women suffered sexual violence. Also, the study reveals a statistically significant relationship between certain individual factors (age and educational level), the nature of the relationship between spouses (marital conflicts and husband's authoritarianism), social factors (women's tolerance of

\footnotetext{
* PhD student, Sociology Department, University of Sharjah

**Sociology Department, University of Sharjah Correspondence Author
} 
Spousal Violence Against women

marital violence) on the one hand and the vulnerability of married women to violence on the other hand.

\section{Key words:}

Risk factors, violence against married women, UAE 


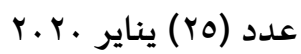

المجلة العربية لعلم الاجتماع

\section{عنف الزوج ضد المرأة في المجتمع الإمارتي}

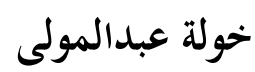

حسين م العثمان

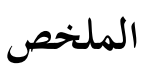

هدفت الدراسة إلى كشف الستار عن حجم العنف وأنماطه الممارسة ضد النساء

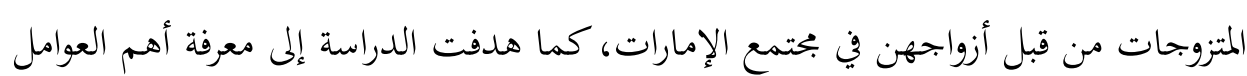

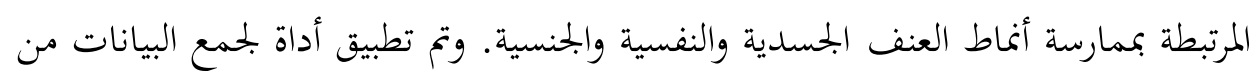

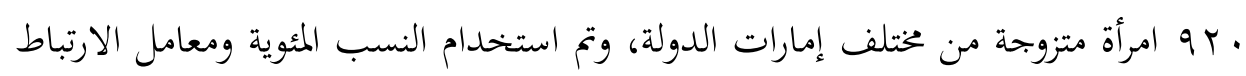
بيرسون ر للإجابة على أسئلة الدراسة وتحقيق أهدافها.

كشفت نتائج الدراسة عن أن العنف النفسي هو الأكثر شيوعا بين النساء المتزوجات،

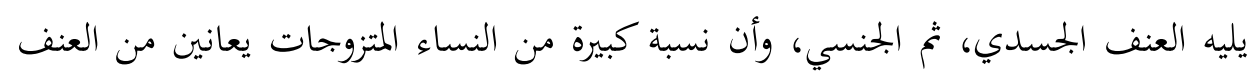

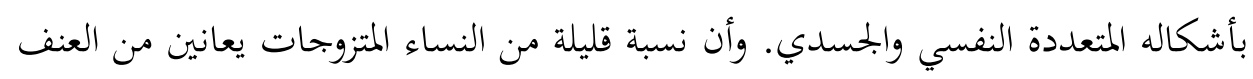

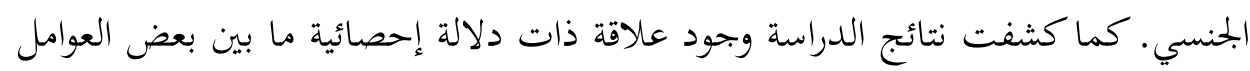
الفردية (العمر والمستوى التعليمي)، وطبيعة العلاقة بين الزوجين (الصراعات الزوجية

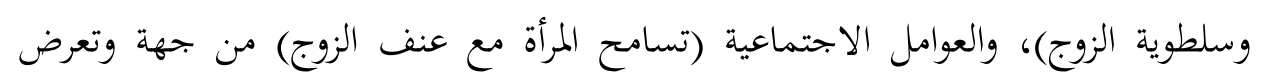

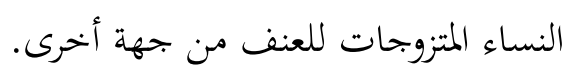

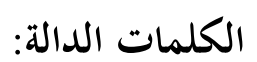
عوامل الخطورة، العنف ضد المرأة المتزوجة، الإمارات العربية المتحدة 
Spousal Violence Against women

\section{Introduction}

Like other social institutions in human societies, the family faces complex social problems such as family violence, poverty, unemployment and environmental problems due to the acceleration of unprecedented social change aspects in human history resulting from social, economic and political factors at the local, regional and international levels. Moreover, family violence has become a social phenomenon that threatens the security of the family and its well being in all human societies in general, and the Arab and Gulf societies in particular. In 1996, the World Health Organization (WHO) adopted a resolution that stipulates that violence should be a public health issue in the world, as it has serious effects on individuals, families and local communities (WHO a, 2002). Violence also constitutes one aspect of the physical, psychological, sexual and emotional sufferings experienced by family members, which is practiced in a hidden manner. Victims of family violence could be young children, who cannot defend themselves, or the elderly (both males and females). What makes the problem even worse is the fact that violence is usually not reported for social reasons (WHO, 2002b). Early research used the terms 'wife abuse' and 'domestic violence' to focus on physical violence experienced by married women. Some researchers have continued to use 'family violence' and 
r.Y. عدد (Yo) يناير

المجلة العربية لعلم الاجتماع

'spouse/partner abuse', as violence has come to be seen as a behaviour perpetrated by both men and women.

The first thing that comes to one's mind is that family is a safe haven and a place where we endeavour to get love, approval, care and where we spend quality time with other family members, especially woman and children. However, this is not true for one in five women at the international level where family can become a source of violent acts and practices that threaten both women and children in particular (Michiri, 2004). The seriousness of violence against women stems from the fact that it is usually not reported. Women as a social category are the victims of family violence perpetrated by an intimate partner, family and non-family members, acquaintances or strangers. Violence is a violation of cultural, human and religious values (Sabbah, et al.,2016). International organizations have shown a clear interest in the issue of violence against woman through developing international rights, convention and policies that protect and prevent violence against women. Although relations between spouses and family relations provide them with a sense of intimacy and well being, these relationships may be accompanied by physical violence, emotional or verbal abuse, sexual abuse or mutual negligence.

The General Assembly of the United Nations (1993) defines violence against women as "any act of genderbased violence that results in, or is likely to result in, physical, sexual, or mental harm or suffering to women, including threats of such acts, coercion or arbitrary 
Spousal Violence Against women

deprivation of liberty, whether occurring in public or in private life". (WHO, 2002b) The World Health Organization (2002a) classifies violence, according to its perpetrators into: (1) self-directed violence such as completed suicide, attempted suicide or self-abuse; (2) interpersonal violence which includes family violence occurring among those who are closely related to the victim and it usually takes place within the family, and community violence that occurs among members who are not related outside the home such as gang violence, rape, violence in schools, workplaces, prisons, etc.; and (3) collective violence such as social, political or economic violence. According to this classification, the violence inflicted upon the wife by her husband (also called intimate partner violence) is a form of interpersonal violence.

\section{Research Problem}

The UAE family, like other Gulf and Arab families, has witnessed changes in its social structure, especially in the post-oil-discovery period as a national wealth that resulted in a planned social change in various aspects of social, economic and political life. Despite these structural changes in the Emirati family, there are insufficient studies on the problem of family violence or violence against women in general or married women in particular. This study is expected to uncover the magnitude of and patterns of violence against married 
women perpetrated by their husbands, and some of the factors that have to do with these patterns.

There are multiple stakeholders in the UAE community, such as police departments, family counselling centers, family development institutions and social support centres concerned with issues of family violence or violence against women. Social support centres receive social violence cases that are studied by social workers who do not have any form of professional level practice in the field of violence. They coordinate with specialized parties such as family counselling centres and family development institutions to come up with solutions. In case there is no shelter for the person being victimized by violence, he/she is accommodated in designated centres until a solution is found. In case of failure to reach a solution, the case is referred to the court for appropriate action in accordance with the law; hence, shelters for women and children affected by violence of prided.

The UAE society lacks any special legislation or laws on family violence or violence against women. This does not mean that in the event of an attack on women, there would be no protection for the offended party. Indeed, protection is available but it is scattered across the laws, especially in the penal codes, which criminalize most forms of abuse to people in general. However, these laws do not serve the best interests of the family or women within a specific context that ensures the protection and privacy of the family or the woman, as is the case with children, where all cases and issues relating 
Spousal Violence Against women

to them are based on a special law that takes into account the best interests of the children. The penal code punishes insults, defamations, threats, and crimes committed on the body or relating to sexual violence of all kinds, all of which can be applied to women in case of being under assault. Article 15 of the UAE Constitution stipulates that the family is the basis of society and it is founded on religion, ethics and patriotism. Moreover, the law guarantees its existence, and protects and safeguards it from depravity and corruption.

Specifically, the study attempts to answer the following questions:

1. What is the dimension of violence and its patterns, experienced by married women from their husbands in the UAE society?

2. Do the patterns of violence perpetrated against married women in the UAE society differ according to individual and social factors, marital relationships and the nature of the local community?

\section{Theoretical Background}

There are a number of sociological explanations for violence against women. The feminist perspective focuses on gender inequality that appears in the form of women's subordination to the authority and control of men, which results in inflicting different forms of violence upon women (Kruz, 1993; Yllo, 1993). This relationship is 
rooted in the social structure of patriarchal families and it is supported by economic and political institutions. Therefore, women would have a low position in social relations in terms of power and benefits in society. This theory explains violence against the wife on the basis of gender analysis where, by abuse or violence against, the wife is viewed as normal violence that is utilised by males to establish and maintain power and control over women. This theory rejects the psychological explanation of a wife's abuse, which emphasizes that abuse relates to individual characteristics rather than culture. It shows how, a wife's abuse results from social norms that privilege or ascribe higher status to men over women. Feminist theory claims that the society is patriarchal and that violence perpetuates male dominance, which is reinforced by women's dependence on men, and renders it acceptable in society. Therefore, feminism sees patriarchy as the direct cause of a wife's abuse (Dutton, 2006). For example, some studies have revealed a relationship between patriarchal social structures and patriarchal control on the one hand and violence against women on the other (Betterman, 2009). Also, Kishor and Johnson (2004) found that men are being raised to use force to control women and that men's behaviour, which is characterized by more control over women, increases the risk of women being exposed to violence by men. Some studies have also found (e.g. Hoque et al., 2009) that women with lower social status represented by low educational level and unemployment are more likely to be targets of family violence. 
Spousal Violence Against women

Another theoretical model that explains violence is the ecological model, which focuses on the multiplicity of factors that explain the phenomenon of violence, the reasons that make some individuals behave violently towards others, or the reasons that render violence more widespread among some individuals and communities. According to this model, violence is the result of complex interactions between the individuals, the relationship, the community, and societal factors. The knowledge of how these factors are linked to the phenomenon of violence is one of the basic steps towards a public health approach to prevent violence (WHO, 2002a). The individual factors relate to the demographic and social characteristics of individuals as well as to biological factors and personal history (exposure to violence and perpetrating violence later). Individual factors also include other factors such as impulsion, low education level, and drug addiction. In other words, these individual factors make it more likely that people become victims or perpetrators of violence. The relationship factors in the ecological model focus on intimate social relationships (colleagues, peers, and family members) that increase the risk of violence as a victim or a perpetrator. For example, some children are more likely to experience abuse and violence with a drug addict in the family, which could be repeated due to joint residence as well as the nature of relationship in the family. 


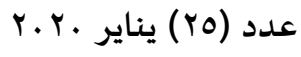

المجلة العربية لعلم الاجتماع

The community level in the ecological model is concerned with the environmental community (social policies) that abound with social relations such as schools, workplaces, neighbourhoods, and factors relating to population density in neighbourhoods, communities with increasing drug trade and high levels of unemployment, or social isolation (where people do not know their neighbours, or they do not participate with local communities in joint activities), or living in poor areas (poor health and lack of institutional support). These factors contribute to exposure to violence and to experiencing it as a victim or perpetrator.

The societal level in the ecological model discusses the impact of social factors that create and endorsee violent climate. Among these societal factors are social norms that encourage and justify violence as an acceptable method of conflict resolution, norms that give priority to the rights of parents over the interests of children, norms that support male domination over women and children, and social policies that maintain inequality among the different groups in the society (WHO, 2002 a).

\section{Literature Review}

There is a paucity of empirical studies on the family in general, and on violence against women in particular in the UAE society, so the focus here will be on previous relevant studies conducted in some Arab countries (Egypt, Jordan, Lebanon, Saudi Arabia) and some foreign countries (USA, Canada, Australia). Mutawa and Hassan (2006), based on a sample of 300 students at the UAE university, conducted a study on the physical 
Spousal Violence Against women

and psychological patterns of violence in the UAE society and found that the most vulnerable members of the society to violence were women and children. It also point out that battering and insults were among the most common forms of violence. Also, the study shows that although the majority of respondents believed that violence had negative and serious effects on mental health and socialization, respondents endorsed violence claiming that it has positive effects on social control and protection from depravity and corruption.

A WHO study of 10 countries found that between 15 and 71per cent of the women in the survey experienced physical or sexual violence, or both in their lifetimes, and 4 to 54 per cent of the women in the survey reported that they had been subjected to violence during the 12 months before the survey (Garcia-Moreno et al. 2006). The results of 10 demographic and health surveys showed that between 16 and 75 per cent of the female respondents experienced physical or sexual violence from the current spouse or partner and between 10 and 33per cent said they had experienced violence from their spouses or their partners during the 12 months preceding the survey (Hindin et al. 2008).

In Saudi Arabia, Al-Khatib's study (2005) reveals that the most common type of violence among cases of violence against women who attended Riyadh Central Hospital and the Charity Center for Social Counselling was 
physical and psychological violence together, followed by physical violence only, and psychological violence only, respectively. The study also found that the majority of violence was committed by the elder brother, followed by the father, and that the violence decreased as women progressed in age. The causes of family violence against women were attributed to parents' doubt about their daughters' actions, fear of depravity or "to discipline women". The rate of violence increases among women with intermediate and secondary education, and decreased among university degree holders. The study also found that employed women were less vulnerable to violence than unemployed women.

In Egypt, Awad's (2006) study compares the crimes of family violence in rural and urban areas in Upper Egypt. The sample of the study comprises 77 cases of family violence by convicts in Egyptian prisons who committed a crime against one or more members with whom they were related by marriage. The study showed that females were more violent than males within the family. The study also revealed three patterns of family violence: fatal physical violence, violence related to alimony and frittering away marital possessions, and moderate physical violence related to battering. The study showed that family violence took different forms, inter alia, spousal violence in first place, violence against in-laws and violence against brothers in second place, violence against children in third place, and violence in general in fourth place. The study found that the majority of the 
Spousal Violence Against women

perpetrators were illiterate, married at an early age, agricultural workers, craftsmen, or low-paid people.

Al-Essawi (2004) conducted a study titled 'The Phenomenon of Family Violence: Causes and Aspects' on a sample of 546 students at Alexandria University. The results of the study revealed that physical violence was the most common form of family violence. The study revealed that domestic violence in Egyptian society took a number of forms such as shaving heads, rape, sexual molestation and murder. Respondents attributed family violence to several factors, the most important of which were: weakness of religiousness, economic factors, unemployment and life pressures. Also, according to ElZanaty and Way (2006) the Demographic and Health Survey results in Egypt (2005) showed that about $36 \%$ of married women were subjected to some form of spousal violence in the year preceding the survey. The survey also found that the most vulnerable to husband's violence were the younger women, the less educated and the poorest.

In Jordan, Al- Badayneh's (2012) study identified the risk factors of violence against woman as follows: lower education, women's employment, watching violence during childhood, and the tendency of women to desert the marital relationship. The study showed that $98 \%$ of women in the national sample experienced some form of violence. Women who had been subjected to 


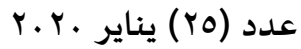

المجلة العربية لعلم الاجتماع (- ماع

violence felt stigmatized, intimidated, and ashamed. Shteiwi et al. (2005) also conducted a study titled 'Family Violence in Jordan: Knowledge, Trends and Reality' on a national sample of 1500 participants. Findings showed that Jordanian respondents were aware of the concept of family violence, but they linked it with physical violence in its various forms in the first place and psychological violence in the second place. The results of the study also showed that males were among the most violent groups within the family. Jordanians attributed family violence to various factors such as alcohol and drug abuse, divorce, anger, lack of respect within the family, love of control, financial difficulties and unemployment. The study found that Jordanians believed that family violence badly affects the family leading to divorce, family conflicts, adverse psychological effects and a loss of respect. Moreover, those who were exposed to violence were found to suffer from problems such as loss of self-confidence, fear, depression, physical harm, isolation, abandoning home, etc. The results of the study indicated that about $14 \%$ of the respondents perpetrated a form of family violence during the 12 months before the survey where the majority of the victims of violence were brothers and sons, followed by sisters, daughters, wives and mothers, respectively. The most common types of family violence were psychological violence and physical violence, respectively.

In the United States, results of national surveys on victims indicated that family violence accounts for $11 \%$ of 
Spousal Violence Against women

all violence while police statistics indicated that cases of family violence constituted about $33 \%$ of cases of violence in America from 1998 to 2002. Also, about half of the cases (49\%) were committed against spouses, and $11 \%$ were committed against children by their parents. Besides, $41 \%$ of the cases were crimes against other family members. The results of the surveys during the same period indicated that simple assault was the most common type of violence, and murder accounted for less than $1 \%$ of all cases of family violence. Surveys showed that about three-quarters of family violence occurred in or around the victim's home, and that $73 \%$ of victims of family violence were males. The results of the national surveys revealed that the majority of perpetrators of family violence (66\%) were aged between 22 and 54 years (Bureau of Justice Statistics, 2005).

Again, Griffith et al. (2006), basedon a sample of 194 Trinidadian and 290 American citizens, conducted a study titled 'Trinidadian and U.S. Citizens' Attitudes toward Domestic Violence and their Willingness to Intervene', The study revealed that Trinidadian citizens were more tolerant than American citizens regarding domestic violence and were less willing to intervene in violence involving a friend, neighbour or co-worker compared to Americans. Results also showed that women, across both nationalities, were less tolerant than men toward violence. Likewise, Baskerville (2006) conducted a study of 
عدد (Y0) يناير .r.Y.

المجلة العربية لعلم الاجتماع

family violence in America. Results revealed a correlation between family violence and family dissolution. The study found that the causes of child abuse were associated with family disintegration and dissolution, and that family policies in America not only fail to protect children from abuse, but they also contribute to this abuse. The study called for the replacement of existing family policies by new suitable policies.

The Australian Federal government (Commonwealth of Australia, 2000) conducted a study entitled 'Attitudes to domestic and family violence in the diverse Australian community' adopting a number of qualitative research techniques (review of previous studies, in-depth interviews and focus group discussions). The results of the study revealed that the majority of respondents had a reasonable understanding of family violence that included physical violence, and psychological, emotional and sexual abuse. Australian respondents were aware that domestic violence was always a serious issue, and that some types were more serious than others, such as emotional violence (because of its long-term psychological impact), especially from the perspective of female respondents. The results showed that women were the victims of violence, and that men were more likely than women to believe that family violence was more widespread. Australians attributed family violence to financial pressures, economic problems, drugs and alcohol abuse, gambling, males' aggressive nature, as well as acquired behaviours (being exposed to violence). Results also revealed that the majority of respondents personally 
Spousal Violence Against women

believed that family violence was unacceptable. Moreover, some of the respondents believed that their communities considered family violence incomprehensible, and unacceptable in some circumstances. Also, the results of the study indicated that the majority of Australian respondents were aware of the negative consequences of family violence for the whole family as well as the local community members. Respondents pointed out that fear and shame among the victims of violence were among the obstacles that prevented victims from reporting and disclosing family violence.

A group of institutions (EKOS Research Associates In., 2002) conducted a study of public attitudes towards family violence in Canada on a sample of more than 2000 respondents and 10 focus group discussions at the national level. The results of the study revealed that Canadians paid considerable attention to family violence. They considered it a top priority issue for the government and the local community. The results of the study showed that the respondents had good knowledge about family violence, its causes and consequences. It was found out that violence came from multiple sources: the media, personal experience of family violence in the respondents' lives, or in the lives of families they knew. However, respondents, unexpectedly, were not aware of the abuse of the elderly 
and financial abuse at the time of the study. The results of the study revealed that there were some obstacles to intervening in cases of family violence such as fear of interference in private family affairs and a lack of knowledge of appropriate actions to be taken in such situations. Canadians differed in their attitudes towards family violence according to gender, social and economic status, and personal engagement in the issue.

Fidan and Bui's study (2016) in Zimbabwe pointed out the importance of the role of gender relations in violence against women. The gender-related behaviours of men increased the likelihood of all forms of violence against women. The study also found that women's employment increased the likelihood of victimization.

Among the risk factors that contribute to women's victimization from violence by their husbands are the individual factors. Some Western studies revealed that the younger and less educated the men, the more likely they were to perpetrate violence against their wives or their partners (Riggs et al. 2009). Some demographic and health surveys in Jordan and Egypt also revealed high rates of violence among men who have less education, and the higher the educational level of women, the less likely they were to be victims of their husbands' violence in Jordan and Egypt (Department of Statistics of Jordan and Macro International Inc. 2008; El- Zanaty and Way, 2006). In Palestine, three surveys also found the risk factors of being a victim of violence from the husband positively correlated with lower education and younger age among women (Haj-Yahia 2000, 2010). 
Spousal Violence Against women

Other risk factors relate to the relationship between spouses or partners. Men attempt to maintain their power and control over women in the Arab world. This, besides large family sizes and tensions in the family, would increase the risk factors of violence between couples ( $\mathrm{Haj}$ Yahia's and Clark, 2013; Stith and McMonigle, 2009). In Jordan, some studies revealed that large family sizes (Clark, 2011), low decision-making power among women (Department of Statistics of Jordan and Macro International Inc. 2008), and conflicts between women and their husbands increased the likelihood of women being vulnerable to violence from their husbands (Clark et al., 2009). Furthermore, social factors represented by social norms that support violence against women are also risk factors that contribute to violence against women (Haj-Yahia and Clark, 2013; Abramsky et al., 2011).

\section{Measures and Sampling Procedures}

\section{Dependent Variables}

This study deals with husbands' violence against their wives in the UAE society as a dependent variable. To measure violence against married women, the study uses a number of items that relate to the dimensions of physical, psychological and sexual violence. After verification of the items, the number of items relating to violence against women was19: physical violence (7 items), psychological violence ( 8 items), and sexual violence (4 items). To measure violence, the 
عدم (ro) يناير .r.T.

المجلة العربية لعلم الاجتماع

commands 'compute' in the Statistical Package for the Social

Sciences

Program (SPSS)

were

used. Accordingly, the physical scale for violence ranges from 7 to28. That is, the values of the scale of physical violence cannot be less than 7, (if the female respondent's answers to the items that ask about whether she was exposed to any form of physical violence by her husband were all in the negative (never =1)). Similarly, the values of this scale cannot exceed $28(7 * 4)$ (if the female respondent's answers to all the items of the scale were that she was always subjected to physical violence (always $=4$ ), that will add up to 28). The psychological violence scale runs from 8 to 32, while the sexual violence scale ranges from 4 to 16 .

The minimum figures indicate that the respondent was not exposed to violence in its various forms by her husband, while the maximum number indicates that she was always subjected to violence in its various forms by her husband (see items 'violence against married women in Table 2). The following question was posed to identify the forms of violence experienced by married women: Have you ever been exposed to any form of violence from your husband during your married life? Please select the answer that best describes your experience: (1) I have never been subjected to any form of violence, (2) seldom, (3) sometimes, and (4) always. Also, the respondents were asked to add any other forms of violence in case they have been exposed to them.

Independent Variables 
Spousal Violence Against women

The independent variables of the study were measured as given in Tables 1 and 2. According to the literature on violence against women, there are four factors related to violence against women, namely individual factors (age, educational level, working status), factors relating to marital relationships (husband's dominating behaviour and marital conflicts), societal factors (women's acceptance of violence and sexual assaults), and factors related to the local community (region).

\section{Research Participants}

A questionnaire was administered to married women in region (1) Abu Dhabi, Dubai, Sharjah and region (2), the rest of the emirates during May, June and July in the year 2017. The number of respondents was 1,000 married women aged 18 years and above. The number of completed questionnaires was 920 (with an overall response rate at 92\%). Table 1 below presents the demographic and social characteristics of the respondents. 


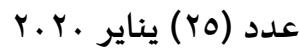
المجلة العربية لعلم الاجتماع

Table 1. Distribution of respondents by sociodemographic characteristics $(\mathrm{N}=920)$

\begin{tabular}{|c|c|c|c|}
\hline \multicolumn{2}{|l|}{ Variables } & Frequency & Percentage\% \\
\hline \multirow{4}{*}{ Age } & $20-30$ & 54 & 5.9 \\
\hline & $31-40$ & 462 & 50.2 \\
\hline & Over 40 & 404 & 43.9 \\
\hline & Total & 920 & 100 \\
\hline \multirow{5}{*}{ Level of education } & Illiterate & 40 & 4.3 \\
\hline & $\begin{array}{l}\text { Secondary and } \\
\text { less }\end{array}$ & 366 & 39.8 \\
\hline & University & 504 & 54.8 \\
\hline & $\begin{array}{ll}\text { Higher } & \text { than } \\
\text { university } & \\
\end{array}$ & 10 & 1.1 \\
\hline & Total & 920 & 100 \\
\hline \multirow{3}{*}{ Working Status } & Employed & 736 & 80 \\
\hline & Unemployed & 184 & 20 \\
\hline & Total & 920 & 100 \\
\hline \multirow{3}{*}{ Region } & Region 1 & 790 & 85.9 \\
\hline & Region 2 & 130 & 14.1 \\
\hline & Total & 920 & 100 \\
\hline \multirow{3}{*}{ Nationality } & Emirati & 598 & 65 \\
\hline & Non-Emirati & 322 & 35 \\
\hline & Total & 920 & 100 \\
\hline \multirow{5}{*}{$\begin{array}{l}\text { Husband's level of } \\
\text { education }\end{array}$} & Illiterate & 104 & 11.3 \\
\hline & $\begin{array}{l}\text { Secondary and } \\
\text { less }\end{array}$ & 550 & 59.3 \\
\hline & University & 60 & 6.5 \\
\hline & $\begin{array}{l}\text { Higher than } \\
\text { university }\end{array}$ & 206 & 22.4 \\
\hline & Total & 920 & 100 \\
\hline \multirow{3}{*}{$\begin{array}{l}\text { Husband's working } \\
\text { status }\end{array}$} & Employed & 800 & 87 \\
\hline & Unemployed & 120 & 13 \\
\hline & Total & 920 & 100 \\
\hline
\end{tabular}

Table 2 also shows some of the characteristics relating to the nature of the husband's behaviour as an indicator of 
Spousal Violence Against women

the nature of marital relationships in the study sample and the extent to which married women in the sample accept violence. These two variables were considered as independent variables to determine the relationship between social factors and factors related to marital relationships with respect to perpetrating violence on married women. This is in addition to the individual factors represented by some of the respondents' characteristics such as age, educational level and working status. As for region, it was dealt with as an independent variable as it reflects the impact of the local community on violence perpetrated against married women. Also, nationality was added to social factors reflecting differences in culture and lifestyle.

Table 2. Distribution of respondents according to the nature of marital relationships and acceptance of intimate violence

\begin{tabular}{|c|c|c|c|c|c|c|c|c|}
\hline \multirow{2}{*}{$\begin{array}{l}\text { Relationship } \\
\text { Factors }\end{array}$} & \multicolumn{2}{|c|}{ Always } & \multicolumn{2}{|c|}{ Sometimes } & \multicolumn{2}{|c|}{ Seldom } & \multicolumn{2}{|c|}{ Never } \\
\hline & $\mathbf{F}$ & $\%$ & $\mathbf{F}$ & $\%$ & $F$ & $\%$ & $\mathbf{F}$ & $\%$ \\
\hline $\begin{array}{l}\text { Husband's } \\
\text { dominating } \\
\text { behaviour }\end{array}$ & 200 & $21 \%$ & 250 & $27 \%$ & 100 & $10 \%$ & 370 & $40 \%$ \\
\hline $\begin{array}{l}\text { Marital } \\
\text { conflicts }\end{array}$ & 150 & $16 \%$ & 80 & $8.6 \%$ & 120 & $13 \%$ & 570 & $61 \%$ \\
\hline \multicolumn{9}{|l|}{ Social Factors } \\
\hline $\begin{array}{l}\text { Women's } \\
\text { acceptance of } \\
\text { their husbands' } \\
\text { violence }\end{array}$ & 190 & $20 \%$ & 130 & $14 \%$ & 100 & $10 \%$ & 500 & $54 \%$ \\
\hline
\end{tabular}


ع.r. عدد (Yo) يناير

المجلة العربية لعلم الاجتماع

\section{Validity and Reliability}

To ensure the validity of the measurements of violence against married women, the tool of the study was presented to and discussed with specialist professors who provided insightful feedback on the questions and amendments to some items were made accordingly, while some items were completely omitted. The number of items was 19 in all scales (physical, psychological and sexual violence). After that, the questionnaire was tested by interviewing 60 respondents of the same sample who were asked to fill out the questionnaire to ensure clarity and validity of the questionnaire questions.

The stability of the internal consistency of the items of the measures of violence against married women was also calculated. The value of Cronbach alpha was calculated in order to ensure internal consistency between the items of each explanatory factor of the measures of violence. Table 3 shows that the highest value of Cranach alpha was 0.85 for the items of violence against married women relating to sexual violence while the lowest value (0.79) was for the items of violence against married women relating to psychological violence. In general, the overall rate of Cronbach alpha for all items stood at 0.81, which is fairly high and acceptable. 
Spousal Violence Against women

Table 3. Cronbach alpha values of violence against married women (VAMW) dimensions

\begin{tabular}{|l|l|l|l|l|l|}
\hline No. & $\begin{array}{l}\text { Violence against married } \\
\text { women - dimensions }\end{array}$ & Mean & SD & $\begin{array}{l}\text { No. of } \\
\text { items }\end{array}$ & \\
\hline 1 & Physical violence & 10.7935 & 1.81121 & 6 & 0.80 \\
\hline 2 & Psychological violence & 10.7935 & 1.81121 & 8 & 0.79 \\
\hline 4 & Sexual violence & 5.1087 & 1.37010 & 4 & 0.85 \\
\hline 5 & Overall & & & 18 & 0.81 \\
\hline
\end{tabular}

\section{Analysis and Discussion}

The descriptive statistics (percentages) analysis was used to answer the first question that relates to the amount of violence and its forms that married women were exposed to by their husbands. The results of the statistical analysis, presented in Table 4, reveal that the most common forms of violence against married women were psychological violence, physical violence, and sexual violence, respectively. Percentage means of psychological violence faced by married women 'always' throughout their married life reached $16.5 \%$, while 'sometimes' reached $22 \%$ and 'seldom' was $8 \%$, with a total of $46.5 \%$. Percentage means of the items of physical violence experienced throughout their married life by married women 'always' stood at 9\%; 'sometimes' at 16\%; and 'seldom' at $7.6 \%$ with a total of $32.6 \%$ while sexual violence reached 'always' at $4 \%$, 'sometimes' at $7.2 \%$, and 'seldom' at $2.7 \%$, totalling $13.9 \%$. 


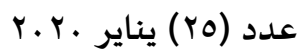

المجلة العربية لعلم الاجتماع

Data in Table 3 show that the respondents in the study sample had been subjected to multiple forms of psychological violence during their marriage, with insults and verbal abuse being the most common forms committed 'always' or 'sometimes' by husbands against their wives at (65\%), followed by yelling (54\%), blame (49\%), threat of divorce (38\%), silence and ignoring (33\%), constant criticism (30\%), cynicism $(26.6 \%)$, and finally house arrest (11\%).

Table 3 also shows that the most common type of physical violence perpetrated by husbands against their wives was pushing them 'always' or 'sometimes' during married life (36\%), followed by beating them with their head-cords 'always' or 'sometimes' (33\%), followed by throwing things $(33 \%)$, slapping $(31 \%)$, spitting on the face $(24 \%)$ and finally manual strangulation (7.6\%).

The data in Table 3 also show that the least type of violence against women by their husbands was sexual violence. Results revealed that $22 \%$ of the married women in the sample had been sexually abused by their husbands 'always' or 'sometimes', 11\% were forced to have sex with their husbands against their desire 'always' or 'sometimes', while $8 \%$ of married women were deserted by their husbands, and a few of them (4\%) were forced to have inappropriate sexual practices during their marital life 'always' or 'sometimes'.

To summarize, large proportions of married women in the UAE society suffer from psychological and physical violence, and a few of them suffer from sexual violence. This result is consistent with some studies in the societies in which violence against women is widespread, as in Egypt

1 a cord that is worn by some Arab men to keep the head cover in place. 
Spousal Violence Against women

(Demographic and Health Survey of Egypt, 2005), Jordan (AlBadayneh, 2012), Palestine (Haj-Yahia and Clark, 2013) and some Western societies (Garcia- Moreno etal., 2006). It is worth pointing out the high rates of violence among married women in the sample is due to the fact that the question in the questionnaire asks about violence during married life and not within a specified period, as in other studies where it is restricted to a year before the survey. Also, the results can be accounted for by the fact that the UAE society is undergoing a transitional period where traditional and modern values coexist - a period that is mostly characterized by continued strength and control of men over women as well as the prevalence of expressive characteristics of the society, which explains the high rate of psychological violence despite the achievement of social welfare in the field of human development in the UAE society.

Table 4.Mean percentages of the responses of married women about forms of violence perpetrated upon them during their marriage

\begin{tabular}{|l|l|l|l|l|l|l|l|l|}
\hline \multirow{2}{*}{$\begin{array}{l}\text { Dimensions of } \\
\text { violence }\end{array}$} & \multicolumn{2}{|l|}{ Always } & \multicolumn{2}{l|}{ Sometimes } & \multicolumn{2}{l|}{ Seldom } & \multicolumn{2}{l|}{ Never } \\
\cline { 2 - 10 } & F & $\%$ & F & $\%$ & F & $\%$ & F & $\%$ \\
\hline Physical violence \\
\hline Slapping & 93 & $10.1 \%$ & 199 & $21 \%$ & 18 & $1.9 \%$ & 610 & $67 \%$ \\
\hline Pushing & 120 & $13 \%$ & 210 & $23 \%$ & 90 & $10 \%$ & 500 & $54 \%$ \\
\hline $\begin{array}{l}\text { Manual } \\
\text { strangulation }\end{array}$ & 50 & $5.4 \%$ & 20 & $2.2 \%$ & 50 & $5.4 \%$ & 800 & $87 \%$ \\
\hline $\begin{array}{l}\text { Spitting on the } \\
\text { face }\end{array}$ & 75 & $8 \%$ & 145 & $16 \%$ & 240 & $26 \%$ & 460 & $50 \%$ \\
\hline $\begin{array}{l}\text { Beating with } \\
\text { head-cord }\end{array}$ & 100 & $11 \%$ & 200 & $22 \%$ & 20 & $2 \%$ & 600 & $65 \%$ \\
\hline Throwing & 90 & $10 \%$ & 210 & $23 \%$ & 30 & $3 \%$ & 590 & $64 \%$ \\
\hline
\end{tabular}




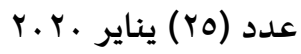

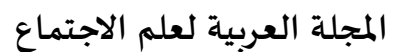

\begin{tabular}{|c|c|c|c|c|c|c|c|c|}
\hline things & & & & & & & & \\
\hline $\begin{array}{l}\text { Threatening } \\
\text { with sharp } \\
\text { objects }\end{array}$ & 50 & $5.4 \%$ & 20 & $2.2 \%$ & 50 & $5.4 \%$ & 800 & $87 \%$ \\
\hline $\begin{array}{l}\text { Mean } \\
\text { percentages }\end{array}$ & & 8.99 & & 16 & & 7.67 & & 68 \\
\hline \multicolumn{9}{|c|}{ Psychological violence } \\
\hline $\begin{array}{l}\text { Insults and } \\
\text { verbal abuse }\end{array}$ & 200 & $22 \%$ & 400 & $43 \%$ & 50 & $5.4 \%$ & 270 & $29 \%$ \\
\hline Yelling & 150 & $16 \%$ & 350 & $38 \%$ & 120 & $13 \%$ & 300 & $33 \%$ \\
\hline $\begin{array}{l}\text { Constant } \\
\text { criticism }\end{array}$ & 140 & $15 \%$ & 140 & $15 \%$ & 150 & $16 \%$ & 490 & $53 \%$ \\
\hline House arrest & 40 & $4 \%$ & 60 & $7 \%$ & - & $0 \%$ & 820 & $89 \%$ \\
\hline $\begin{array}{ll}\begin{array}{l}\text { Silence } \\
\text { ignoring }\end{array} & \text { and } \\
\end{array}$ & 180 & $20 \%$ & 120 & $13 \%$ & 20 & $2 \%$ & 600 & $65 \%$ \\
\hline Cynicism & 160 & $17 \%$ & 80 & $9.6 \%$ & 70 & $8 \%$ & 610 & $66 \%$ \\
\hline Blame & 250 & $27 \%$ & 200 & $22 \%$ & 150 & $16 \%$ & 320 & $35 \%$ \\
\hline $\begin{array}{ll}\text { Threat } & \text { of } \\
\text { divorce } & \\
\end{array}$ & 100 & $11 \%$ & 250 & $27 \%$ & 20 & $2 \%$ & 550 & $60 \%$ \\
\hline $\begin{array}{l}\text { Mean } \\
\text { percentages }\end{array}$ & & 16.5 & & 22 & & 8 & & 54 \\
\hline \multicolumn{9}{|l|}{ Sexual violence } \\
\hline $\begin{array}{l}\text { Having sex with } \\
\text { husband } \\
\text { against wife's } \\
\text { desire missing } \\
\text { information }\end{array}$ & 25 & $3 \%$ & 75 & $8 \%$ & 20 & $2 \%$ & 800 & $87 \%$ \\
\hline $\begin{array}{l}\text { Inappropriate } \\
\text { sexual practices }\end{array}$ & 20 & $2 \%$ & 20 & $2 \%$ & 10 & $1.1 \%$ & 870 & $95 \%$ \\
\hline Desertion & 19 & $2 \%$ & 51 & $6 \%$ & 30 & $3 \%$ & 820 & $89 \%$ \\
\hline $\begin{array}{l}\text { Causing harm in } \\
\text { sexual intimacy }\end{array}$ & 85 & $9 \%$ & 115 & $13 \%$ & 50 & $5 \%$ & 670 & $73 \%$ \\
\hline $\begin{array}{l}\text { Mean } \\
\text { percentages }\end{array}$ & & 4.00 & & 7.2 & & 2.77 & & 86 \\
\hline
\end{tabular}

The Relationship of Some Variables to Violence Against Married Women by their Husbands

The central question in this study relates to the most important factors related to husbands' violence against their 
Spousal Violence Against women

wives. A Pearson correlation coefficient was computed to assess the relationship between some individual and social factors, and the marital relationships as well as the nature of the local community on the one hand, and measures of violence against married women on the other. As can be seen from Table 5, there was a positive correlation between some individual factors (variables) i.e. age, educational level of the couple, marital relationships factors i.e. husband's dominating behaviour and marital conflicts, and social factors i.e. women's acceptance of violence, and measures of violence against women. In contrast, results show that there was no statistically significant correlation between nationality, working status, and region on the one hand and measures of violence against married women on the other hand.

With regard to individual factors, results of the statistical analysis given in Table 5 showa weak but statistically significant negative correlation between the variables of age, and educational level of the couple on the one hand and the vulnerability of married women to psychological, physical and sexual violence from their husbands on the other hand. In other words, the older and the higher the educational levels of both spouses, the less likely women are exposed to violence. The results of this study are consistent with of the results of some previous studies (Al- Khateeb, 2005; Demographic and Health Survey, Egypt, 2005; AlBadayneh, 2012; Al-Teer, 1997; Riggs et al., 2009; Department of Statistics of Jordan and Macro international Inc. 2008; HajYahia, 2000, 2010). Results of the study given in the same table also show that there were no statistically 
significant associations between the variable 'working status of the couple' and violence against married women in its multiple forms, i.e. exposure of married women to violence is not affected by the working status of the husband or the wife.

As for the variables of marital relationships, statistical results given in Table 5 show that there was a weak-tomedium correlation between the variables of 'husband's dominating behaviour' and 'marital conflicts' on the one hand, and the vulnerability of married women to psychological, physical and sexual violence from their husbands on the other. In other words, marital conflicts and husband's controlling behaviour in the marital relationship increase the likelihood of husband's violence against his wife. Also, marital conflicts and the traditional roles of men controlling women undermine positive communication and participation in decision-making, mutual understanding, respect and quality time together characteristics that distinguish cohesive families. The results of this study are consistent with some of the results of previous studies (Al-Badayneh, 2012; Haj-Yahia and Clark, 2013; Stith and McMonigle, 2009). 
Spousal Violence Against women

Table 5. Pearson correlation values between independent variables and dimensions of VAMW

\begin{tabular}{|c|c|c|c|}
\hline \multirow{2}{*}{$\begin{array}{l}\text { Independent } \\
\text { Variables (factors) }\end{array}$} & \multicolumn{3}{|c|}{ Dimensions of violence against married women } \\
\hline & $\begin{array}{l}\text { Physical } \\
\text { violence }\end{array}$ & \begin{tabular}{|l} 
Psychological \\
violence
\end{tabular} & $\begin{array}{l}\text { Verbal } \\
\text { violence }\end{array}$ \\
\hline \multicolumn{4}{|l|}{ Individual factors } \\
\hline Age & $-0.130 *$ & $-0.120 *$ & $-0.133^{*}$ \\
\hline Wife's education & $-0.289 *$ & $-0.305^{*}$ & $-0.350 *$ \\
\hline Husband's education & $-0.307^{*}$ & $-0.350 *$ & $-0.300 *$ \\
\hline $\begin{array}{ll}\text { Wife's } & \text { working } \\
\text { status }\end{array}$ & 0.004 & 0.015 & 0.030 \\
\hline $\begin{array}{l}\text { Husband's working } \\
\text { status }\end{array}$ & 0.013 & 0.022 & .005 \\
\hline \multicolumn{4}{|l|}{ Relationship factors } \\
\hline $\begin{array}{l}\text { Husband's } \\
\text { dominating } \\
\text { behaviour }\end{array}$ & $0.422 *$ & $0.380 *$ & $0.450 *$ \\
\hline Marital relationships & $0.301 *$ & $0.323 *$ & $0.339 *$ \\
\hline \multicolumn{4}{|l|}{ Social factors } \\
\hline $\begin{array}{l}\text { Women's } \\
\text { acceptance } \\
\text { violence }\end{array}$ & $0.489 *$ & $0.499 *$ & $0.455 *$ \\
\hline Nationality & 0.067 & 0.018 & 0.011 \\
\hline \multicolumn{4}{|l|}{ Community factors } \\
\hline Region & -0.002 & -0.025 & -0.006 \\
\hline
\end{tabular}

*correlation is significant at 0.05 level.

From the statistical analysis given in Table 5, it is ardent that social factors represented by the degree of women's acceptance of violence by their husbands, play the strongest role in increasing the likelihood of exposure to forms of psychological, physical and sexual violence. There was a moderate positive correlation between the degree 


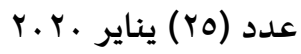

المجلة العربية لعلم الاجتماع

of women's acceptance of violence by their husbands on the one hand and measures of husbands' violence against their wives. This can be explained by the fact that women are more tolerant to their husbands' violence, which increases the likelihood of husbands' psychological, physical and sexual violence. This is due to the nature of socialization in traditional communities or communities living in a transition from traditional to modern life, which requires women to maintain their family stability and endure what is inflicted upon them for the sake of their children, their husbands and their family. This result is in line with some previous studies (HajYahia and Clark, 2013; Abramsky, et al., 2011).

In general, the association between marital relationships and social factors, and violence against married women by their husbands in the UAE society can be explained as an expression of women's subordination to the inrooted authority of the man in the social structure of the society of the UAE, which is the interpretation from the feminist perspective. The ecological view also reinforces this interpretation by attributing violence to multiple factors related to marital relationships, culture and social norms that support the domination of males over females.

On the other hand, statistical results indicate that the nationality variable does not play any role in the measures of violence against married women. That is, the forms of violence against married women do not differ whether the wife was an Arab or Emirati. Finally, with respect to the factor of UAE regions, results (see Table 5) again indicate that the variable 'region' (comparing those who live in Abu Dhabi, Dubai or Sharjah with those who live in Fujairah, Ajman, Ras Al-Khaimah or Umm Al-Quwain) does not have any statistically significant correlation with the measures of violence against 
Spousal Violence Against women

married women. That is, forms of violence against married women do not differ according to the local community where women in the sample live.

\section{Conclusion}

The study has come up with important and scientific results pertaining to a large number of married women in the UAE who suffer from multiple forms of psychological and physical violence during their marriage. Also, a lower percentage of women suffer from various forms of sexual violence. As can be seen from the results of the study, the most important factors that contribute to violence against married women relate to the nature of marital relationships, patriarchal community culture, and tolerance of violence against women in addition to individual factors related to young age and low educational levels that increase the likelihood of women's vulnerability to violence. As a result, this situation requires a revision of social policies on violence against women. It is necessary to enact legislation dealing with issues of violence against women in order to achieve their best interests to maintain their psychological, physical and social health, and to maintain the entity of the UAE family where social capital factors (maintaining marital relationships and curbing aspects of domination by men through the promotion of family cohesion manifested by positive communication skills, participation in decision-making in the family, appreciation and respect) play the strongest role in reducing women's vulnerability to violence from their husbands. It is also vital to conduct more detailed studies adopting multiple approaches that combine quantitative and qualitative 
r.Y. عدد (Yo) يناير

المجلة العربية لعلم الاجتماع

approaches to obtain more comprehensive information, adding new variables related to drug addiction and exposure to violence in childhood and expanding the measurements of the nature of marital and family relationships as well as measuring violence against women during a specific period of time. 
Spousal Violence Against women

\section{References}

1- Abramsky, T., Watts, C.H., Garcia -Moreno, C., Devries, K., Kiss, L., Ellsberg, M., et al.(2011). What factors are associated with recent intimate partner violence? Findings from the WHO multi-country study on women's health and domestic violence. BMC public Health, 11 (109), 1 -17.

2- Al-Badayneh, Diab. 2012. Violence against women. Journal of Family Violence, V 27, No 5: 369-379.

3- Al-Issawi, Abdul Rahman. 2004. The Phenomenon of Family Violence: Causes and Aspects. Security Research Journal (Center for Research and Studies, King Fahd Security College), 28, pp. 223-281. In Arabic.

4- Al-Khatib, Salwa. 2005. Family Violence Against women in Riyadh: A Study of Some Cases in the Riyadh Central Hospital and the Charity Center for Social Counseling and Family Consultations. Riyadh: Center for University Studies for Girls, King Sa'ud University. In Arabic.

5- Al-Mutawa, Mohamed and Taha Hassan. 2006. Violence in the UAE society: Its Forms, Causes and Consequences. Ain Shams Annals of Arts, V. 34, (JulySeptember), pp. 921-971. In Arabic.

6- Al-Teer, Omar. 1997. Family Violence. Publications of Naif Arab Academy for Security Sciences

7- Awad, Al-Sayid. 2006. Crimes of Family Violence in Rural and Urban areas: A Field Study of Crime 
r.Y. عدد (Yo) يناير

المجلة العربية لعلم الاجتماع

Perpetrators of Family Violence in Some Central or Public Prisons in Qena Governorate. Cairo: Research and Social Studies Center. In Arabic. In Arabic.

8- Betterman, C. (2009). Patriarchy: The Predominant Discourse and Font of Domestic Violence. Australian and New Zealand Journal of Family Therapy, 30, 15 28. Doi: 10.1375/ anft. 30.1.15.

9- Baskervill, Stephen. 2006. Family Violence in America: The Truth about Domestic Violence and Child Abuse. American Coalition for Fathers and Children.

10- Commonwealth of Australia. Attitudes to domestic and family violence in the diverse Australian community: Cultural Perspective.

11- Bureau of Justice Statistics. 2005. https://www.bjs.gov/

12- Clark, C .J., Hill, A., Jabbar, K., and Silverman, J.(2009). Violence during pregnancy in Jordan: Its Prevalence and Associated Risk and Protective Factors. Violence Against Women, 15720 -735. Doi: 10. $1177 / 1077801209332191$.

13- Department of Statistics (Jordan) and Macro International Inc. (2008). Jordan Population and family health survey 2007. Calverton: Authors.

14- Dutton, Donald, G. 2006. Rethinking domestic violence. University of British Columbia Press. Ebrary Reader.

15- EKOS Research Associates Inc. 2002. Public Attitudes towards Family Violence: A Syndicated Study: Canada. 
Spousal Violence Against women

16- El-Zanaty, F., and Way, A. (2006).Egypt demographic and health survey 2005. Cairo: Ministry of Health and Population, National Population Council.

17- Fidan, Ahmet and Bui, Hoan. 2016. Intimate partner violence against women Zimbabwe. Violence against women, 22(9): 1075-1069.

18- Garcia-Moreno, C., Jansen, H. A., Ellsberg, M., Heise, L., and Watts, C.H.(2006). Prevalence of intimate partner violence: Findings from the WHO multi-country study on women's health and domestic violence. Lancet, 368(9543), 1260 - 1269. Doi: 10.1016/S0140- 6736(06) 69523-8.

19- Griffith, Sandy-Ann; Charles Negy and Derek Chdee.2006.Trinidadian and U.S. Citizens' Attitudes Toward Domestic Violence and their Willingness to Intervene: Does Culture Make a difference? Journal of Cross - Cultural Psychology, Vol. 37 No. 6,761 - 778.

20- Haj-Yahia, Muhammad and Clark, Cari (2013) Intimate Partner violence in Occupied Palestinian Territory: Prevalence and risk factors. Journal of Family Violence. V 28: 797-809.

21- Haj-Yahia, M.M.(2000) .The incidence of wife abuse and battering and some socio-demographic correlates as revealed by two national surveys in Palestinian society . Journal of Family Violence, 15, 347374.doi:10.1023/1023/A: 1007554229592. 


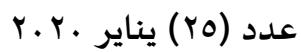

المجلة العربية لعلم الاجتماع

22- Haj-Yahia, M.M.(2002). Beliefs of Jordanian women about wife-beating. Psychology of Women Quarterly, 26,282-291. Doi: 10.1111/1471 -6402.t01-1-00067.

23- Haj-Yahia, M.M.(2010).Wife abuse and beating in the Palestinian society in Israel: Rates, correlates, and mental health consequences. Jerusalem: The Hebrew University of Jerusalem.

24- Hindin, M.J,. Kishor, S., and Ansara, D.L. (2008). Intimate partner violence among couples in $10 \mathrm{DHS}$ countries: Predictors and health outcomes. Calverton: Macro International Inc.

25- Hoque, M.E., Hoque, M., and Kader, S.B.(2009). Prevalence and experience of domestic violence among rural pregnant women in KwaZulu-Natal, South Africa. Southern African Journal of Epidemiology and Infection, 24. Retrieved from

http://www.sajei.co.za/index.Php/SAJEl/article/view/106. 26- Kishor, S., and Johnson, K. (2004). Profiling domestic violence: A multi-country study. Retrieved fromhttp://www.measuredhs.com/pubs/pdf/OD31/O D31.pdf.

27- Kurz,D. (1993). Physical abuse by husbands: A major social problem. In R. Gellesand D.R. Loseke (Eds.) Current controversies in family violence (pp. 88-103). Newbury Park, CA: sage.

28- Mishiri, Robert. 2007. Family violence. Translated by Sidawi, Ali and AdilLutfalla. Second Edition. Abu Dhabi: Research and Security Studies Center: General Directorate of Abu Dhabi Police. In Arabic. 
Spousal Violence Against women

29- Riggs, D.S., Caulfield, M.B., and Fair, K.(2009). Risk of intimate partner violence: Factors associated with perpetration and victimization. In P.M. Kleepies (Ed.), Behavioral emergencies: An evidence-based resource for evaluating and managing risk of suicide, violence, and victimization (pp. 189 - 208). Washington, DC: American Psychological Association.

30- Sabbah, E. A., Chang, Y., \& Campbell-Heider, N. (2016). Understanding intimate partner violence in jordan: Application of the ecological model: Understanding intimate partner violence and ecological model: Application of the ecological model. Perspectives in Psychiatric Care, , n/a. doi:10.1111/ppc.12157

31- Shteiwi, Musa, Shakhatreh, Farouk, Gharaibah, Aweys, Muntha and Aweys, Arwa. 2005. Family violence in Jordan: knowledge, trends and reality. The National Council for Family Affairs, Amman, Jordan. In Arabic.

32- Stith, S.M., and Mc Monigle, C. L. (2009). Risk factors associated with intimate partner violence. In D.J. Whitaker and J.R. Lutzker (Eds.), preventing partner violence: Research and evidence - based intervention strategies (pp.67 - 92). Washington, DC: American psychological Association.

33- www.bureauofjusticesstatistics.2005.family violence statistics 


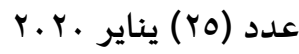

المجلة العربية لعلم الاجتماع

34- Walby,S.A.(1989).Conventional patriarchal ideology of gender relations: An inexplicit predictor of male physical violence against women in families. European Journal of Scientific Research, 36,561-569.

35- World Health Organization. 2002a. World report on violence and health. Cairo. In Arabic.

36- World Health Organization. 2002b. World report on family violence. Translated by Sidawi, $\mathrm{Ali}$ and AdilLutfalla. Second Edition. Abu Dhabi: Research and Security Studies Center: General Directorate of Abu Dhabi Police. In Arabic.

37- Yllo, K.A. (1993). Through a feminist lens: Gender, power, and violence. In R. Gellesand D.R. Loseke (Eds.), Current controversies in family violence (pp. 28 - 51). Newbury Park, CA: Sage. 